\title{
Sources of High Sulfate Aerosol Concentration Observed at Cape Hedo in Spring 2012
}

\author{
Syuichi Itahashi $^{1,2 *}$, Shiro Hatakeyama ${ }^{3,4,5}$, Kojiro Shimada ${ }^{6}$, Akinori Takami ${ }^{7}$ \\ ${ }^{1}$ Environmental Science Research Laboratory, Central Research Institute of Electric Power Industry, Abiko, Chiba 270- \\ 1194, Japan \\ ${ }^{2}$ Department of Marine, Earth, and Atmospheric Sciences, North Carolina State University, Raleigh, NC 27695, USA \\ ${ }^{3}$ Global Innovation Research Organization, Tokyo University of Agriculture and Technology, Fuchu, Tokyo 183-8509, \\ Japan \\ ${ }^{4}$ Graduate School of Agriculture, Tokyo University of Agriculture and Technology, Fuchu, Tokyo 183-8509, Japan \\ ${ }^{5}$ Center for Environmental Science in Saitama, Kazo, Saitama 347-0115, Japan \\ ${ }^{6}$ School of Creative Science and Engineering, Waseda University, Shinjuku, Tokyo 169-8555, Japan \\ ${ }^{7}$ National Institute for Environmental Studies, Tsukuba, Ibaraki 305-8506, Japan
}

\begin{abstract}
Intensive observation campaigns approximately 1 week long were conducted periodically from March 2010 to November 2015 at Cape Hedo, Okinawa, Japan. The maximum daily mean sulfate aerosol $\left(\mathrm{SO}_{4}{ }^{2-}\right) \mathrm{concentrations}^{-}$ surpassed $15 \mu \mathrm{g} \mathrm{m}^{-3}$ in spring 2012. In this study, source apportionment for these high concentrations was conducted using an air quality model with the tagged tracer method, and the main source was identified as volcanoes in March and as anthropogenic emissions from China in April. In March, the prevailing northerly wind transported a volcanic $\mathrm{SO}_{2}$ plume with a low conversion ratio to Cape Hedo. The impacts of 15 volcanoes in Japan were estimated, and a substantial impact from Sakurajima, which accounted for more $\mathrm{SO}_{2}$ than anthropogenic emissions from Japan, was found. Because the model had difficulty capturing the highest concentration, three sensitivity simulations were performed to consider the uncertainty of the volcanic $\mathrm{SO}_{2}$ emission amounts and injection heights, revealing the importance of the injection height in addition to the $\mathrm{SO}_{2}$ emission amount. Throughout April, contributions from anthropogenic emissions from China were found; hence, this source was further divided into 31 provincial scales. Shandong and Jiangsu Provinces, which are the first and seventh largest emission sources in China, respectively, were identified as significant sources at Cape Hedo. These sources showed day-to-day variation in their contributions, and the highest contribution from Shandong Province occurred on April 23, whereas that from Jiangsu Province occurred on April 22.
\end{abstract}

Keywords: Air quality model; Source apportionment; Tagged tracer method; East Asia; Cape Hedo Atmosphere and Aerosol Monitoring Station (CHAAMS).

\section{INTRODUCTION}

Asian air quality is currently the subject of intense interest due to its regional-to-global impacts (Carmichael et al., 2009). Understanding aerosol transformation processes during long-range transport (LRT) is essential for air quality and regional climate change. To achieve this, an intensive observation campaign has been conducted continuously at Cape Hedo Atmosphere and Aerosol Monitoring Station

\footnotetext{
* Corresponding author.

Tel.: 81-70-5080-1394; Fax: 81-4-7183-2966

E-mail address: isyuichi@criepi.denken.or.jp; sitahas@ncsu.edu
}

(CHAAMS), Okinawa, Japan. CHAAMS is at the northern edge of Okinawa Prefecture $\left(26.87^{\circ} \mathrm{N}, 128.25^{\circ} \mathrm{E}, 60 \mathrm{~m}\right.$ above sea level), far from the largest city in Okinawa, Naha City (http://www.nies.go.jp/asia/hedomisaki/home-e.html). There are no large industrial or residential areas near CHAAMS. Air masses are transported to CHAAMS from China, Korea, Japan, Southeast Asia, or the Pacific Ocean depending on the wind pattern. The location of CHAAMS is suitable for capturing the atmospheric pollutants that travel via LRT and has already revealed the behavior of aerosols affected by LRT (Takami et al., 2007; Hatakeyama et al., 2011; Shimada et al., 2015; Shimada et al., 2016; Itahashi et al., 2017a). At CHAAMS, sulfate aerosol $\left(\mathrm{SO}_{4}{ }^{2-}\right)$, which is mainly produced by the oxidation of sulfur dioxide $\left(\mathrm{SO}_{2}\right)$, was the dominant aerosol component (e.g., Tatsuta et al., 2017), as it is across Japan (Chatani et al., 2018). 
Because of the long lifetime of $\mathrm{SO}_{4}{ }^{2-}$ in the atmosphere, LRT is important in downwind regions. To estimate the impact of LRT quantitatively, an air quality model can provide valuable insights (Itahashi et al., 2012a, 2018a). Based on the tagged tracer method, which assigns tracers to track sources, we have been investigating the LRT of $\mathrm{SO}_{4}{ }^{2-}$ over East Asia (Itahashi et al., 2017b; Itahashi, 2018). There has been a lack of comprehensive information at specific receptor sites and detailed time-scales. At CHAAMS, continuous observation campaigns of about 1 week long have been conducted over 6 years from 2010 to 2015 . During these campaigns, the highest $\mathrm{SO}_{4}{ }^{2-}$ concentrations were found in spring 2012 (see "Methods" for detailed description). In this work, we evaluated the sources of $\mathrm{SO}_{4}{ }^{2-}$ during the high concentration episodes based on an air quality model with the tagged tracer method. In our previous study, which revealed the source apportionment at CHAAMS in the autumn (Itahashi et al., 2017a), seven sources of anthropogenic emissions from China, Taiwan, the Korean Peninsula, Japan, and ships, as well as natural emissions, were set. To build on our previous study, more sources were set for a detailed analysis. In China, one of the important sources of $\mathrm{SO}_{4}{ }^{2-}$, source regions were divided into provinces, with a total of 31 regions. For volcanoes as natural sources, the source apportionment to each volcano was investigated. Throughout this study, non-sea salt $\mathrm{SO}_{4}{ }^{2-}$ (referred to hereafter as $\mathrm{SO}_{4}{ }^{2-}$ ) was calculated by the conservative assumption of $\mathrm{Na}^{+}$as a sea salt tracer (Itahashi et al., 2017a) and analyzed to exclude the effect of sea salt.

\section{METHODS}

\section{Observations}

During the intensive observation campaign at CHAAMS, 24-h sampling was performed from 10:00 local time (LT) to 10:00 the next day. A total of 15 campaigns were conducted from 2010 to 2015. $\mathrm{PM}_{2.5}$ was collected on Teflon filters (203 × 254 mm, WP-500-50; Sumitomo Electric, Osaka, Japan) using a high-volume air sampler (HV-1000F; Sibata,
Tokyo, Japan) for $24 \mathrm{~h}$. The $\mathrm{PM}_{2.5}$ sampler was equipped with a $\mathrm{PM}_{2.5}$ impactor developed by Kaneyasu (2010). The samplers were operated at $740 \mathrm{~L} \mathrm{~min}^{-1}$ for $24 \mathrm{~h}$. After sampling, filters were stored in a freezer at $-20^{\circ} \mathrm{C}$. After the campaign, the samples were transported to the lab and the chemical components were analyzed. To analyze the ionic composition, filter samples were ultrasonically extracted with distilled water (specific resistivity $>18 \mathrm{~mol} \mathrm{~L}^{-1} \mathrm{~cm}^{-1}$ ) for $20 \mathrm{~min}$ and distilled water $(10 \mathrm{~mL})$ in a polypropylene tube. $\mathrm{Cl}^{-}, \mathrm{NO}_{3}{ }^{-}, \mathrm{SO}_{4}{ }^{2-}, \mathrm{Na}^{+}, \mathrm{NH}_{4}{ }^{+}, \mathrm{K}^{+}, \mathrm{Mg}^{2+}$, and $\mathrm{Ca}^{2+}$ were analyzed by ion chromatography (LC10AD; Shimadzu, Kyoto, Japan). Anions were separated by an anion analysis column (IC-SA2; Shimadzu, Kyoto, Japan) and detected by a conductivity detector (CDD-10ASP; Shimadzu, Kyoto, Japan) with a suppressor. Cations were separated by a cation analysis column (IC-C4; Shimadzu, Kyoto, Japan) and detected by a conductivity detector (CDD-6A; Shimadzu, Kyoto, Japan) without a suppressor. The eluent was $1.8 \mathrm{~mol} \mathrm{~L}^{-1} \mathrm{Na}_{2} \mathrm{CO}_{3} / 1.7 \mathrm{mmol} \mathrm{L}^{-1} \mathrm{NaHCO}_{3}$ for anions, and $18 \mathrm{mmol} \mathrm{L}^{-1}$ methanesulfonic acid for cations. The concentration of each ionic component (detection limit for each ion of $0.01 \mu \mathrm{g} \mathrm{m}^{-3}$ ) and element was calculated by subtracting the blank value (Yumoto et al., 2015; Taniguchi et al., 2017; Tatsuta et al., 2017; Shimada et al., 2017). The $\mathrm{SO}_{4}{ }^{2-}$ concentrations obtained from the 15 field campaigns are summarized in Fig. 1. The average concentrations for each campaign were from 0.34 to $6.97 \mu \mathrm{g} \mathrm{m} \mathrm{m}^{-3}$, and the average concentration of all observations was $3.13 \mu \mathrm{g} \mathrm{m}^{-3}$. The maximum daily mean concentrations for each campaign are also shown. The highest concentration was observed during the campaign in spring 2012. These campaigns were conducted from March 10 to 17 and from April 22 to 28. The maximum concentrations were $16.91 \mu \mathrm{g} \mathrm{m}^{-3}$ on March 15 and $15.87 \mu \mathrm{g} \mathrm{m}^{-3}$ on April 23.

At Cape Hedo, network observations by the Acid Deposition Monitoring Network in East Asia (EANET) have been conducted by the four-stage filter pack method with a sampling period of 2 weeks. Measured $\mathrm{SO}_{4}{ }^{2-}$ on a Teflon filter in the first stage was analyzed by ion chromatography (EANET, 2013). The monthly, minimum,

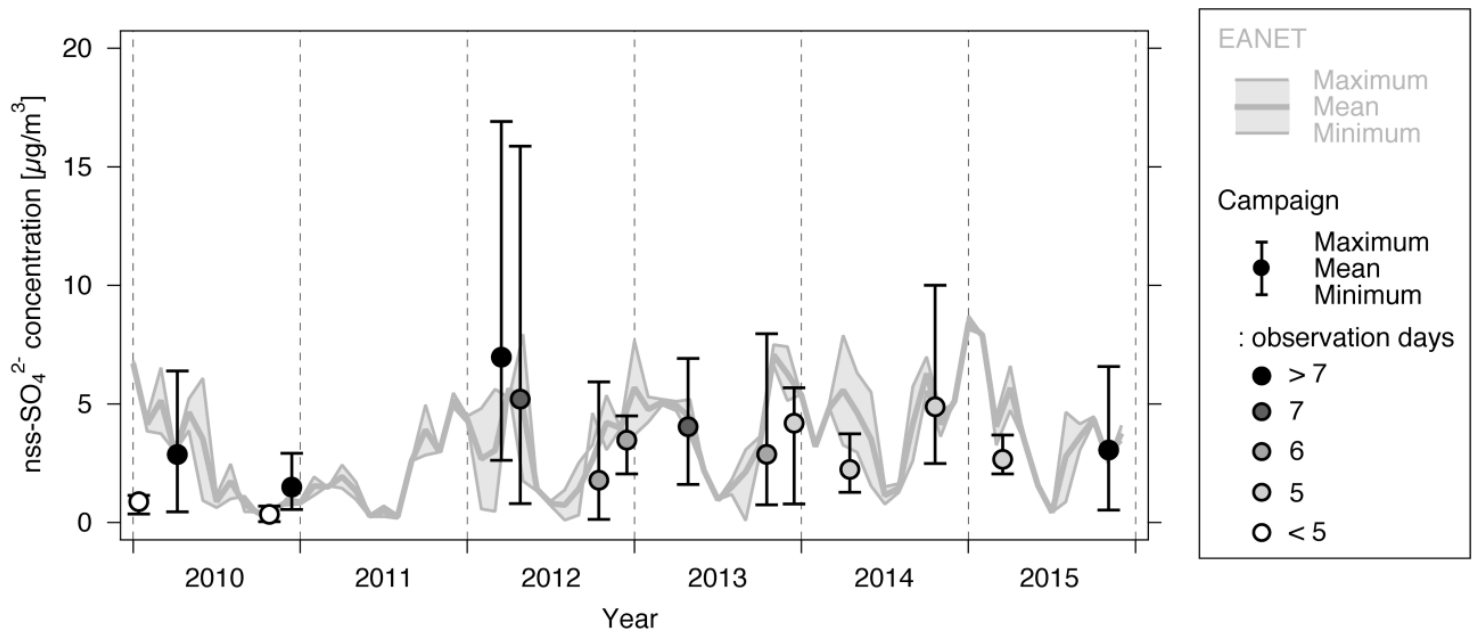

Fig. 1. $\mathrm{SO}_{4}{ }^{2-}$ concentration observed by EANET and during intensive field campaigns at CHAAMS from 2010 to 2015. 
and maximum values for 2-week observation periods are shown in Fig. 1. The value for one observation campaign conducted in January 2010 did not correspond to the monthly mean obtained by EANET, and this can be explained by the short duration of the campaign, with a total of three observations. Except for this one case, the average observation campaign conducted in an approximately 1-week period and the monthly mean observation by EANET were generally consistent. During spring 2012, there was generally a correspondence between average concentrations; however, the daily maximum value was approximately 3 times greater than the average value. Because these concentrations were much higher than those of other campaigns and other monthly averaged EANET data, we sought to explain these episodes based on the air quality model.

\section{Air Quality Model Simulation}

The model simulation was conducted with the regional chemical transport model of the Comprehensive Air Quality Model with Extensions (CAMx) version 6.40 (ENVIRON International Corporation, 2016). CAMx was configured with a 36-km horizontal resolution and $220 \times 140$ grid points, centered at $35^{\circ} \mathrm{N}$ and $115^{\circ} \mathrm{E}$ on a Lambert conformal projection, covering East Asia. The vertical resolution was 37 non-uniformly spaced layers from the surface to $50 \mathrm{hPa}$. This modeling domain was the same as in our previous study (Itahashi et al., 2017a). Gas-phase chemistry was updated to use SAPRC-07 (Carter, 2010), and the aerosol chemistry used the CF scheme, which treats the size distribution as two static fine and coarse modes. CAMx was driven by the meteorological fields calculated by the Weather Research and Forecasting Model version 3.6.1 (Skamarock et al., 2008). The initial and lateral boundary conditions were prepared from the global chemical transport in the Model for Ozone and Related chemical Tracers version 4 (MOZART-4) (Emmons et al., 2010). For the simulations of March and April 2012, a 1-week spin-up time was used.

The emissions inventory for 2012 was prepared as follows. Anthropogenic emissions were based on Hemispheric Transport of Air Pollution (HTAP) version 2.2 for the target year of 2010 (Janssens-Maenhout et al., 2015). China is a particularly important source of anthropogenic emissions globally, although its emissions have gradually decreased after 2005 (Itahashi et al., 2012b). The satellite-based $\mathrm{SO}_{2}$ column observed by the Ozone Monitoring Instrument (OMI) was used to evaluate the emissions variation (Itahashi et al., 2018b). First, for each Chinese province in 2010, the amount of anthropogenic $\mathrm{SO}_{2}$ emissions was compared with the $\mathrm{SO}_{2}$ column (Fig. 2(a)), and the results showed moderate correspondence with a correlation coefficient of 0.59 . Second, the variation in the $\mathrm{SO}_{2}$ column from 2010 to 2012 was calculated by averaging across Chinese provinces. Over eastern-central China, the $\mathrm{SO}_{2}$ column increased, whereas over other provinces it decreased (Fig. 2(b)). Finally, the variation ratio over each province (a)

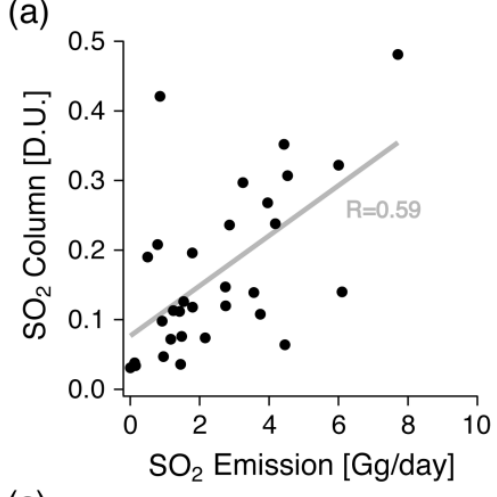

(c)

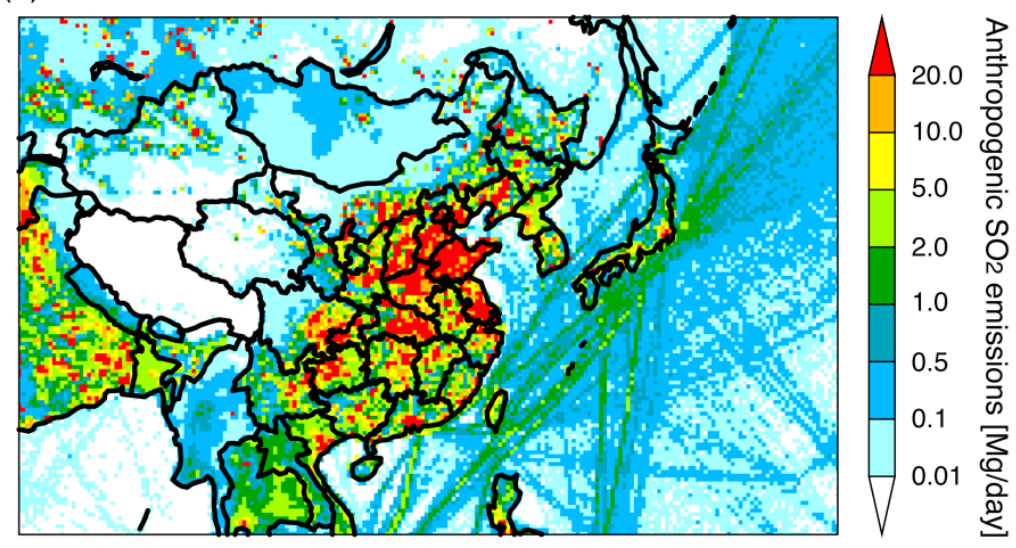

(b)

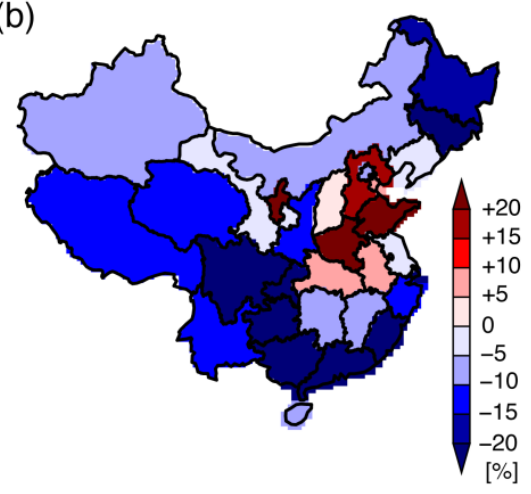


was used to estimate anthropogenic $\mathrm{SO}_{2}$ emissions in 2012. The total amount from China was $76.2 \mathrm{Gg}$ day $^{-1}$, which was slightly lower $(-2.8 \%)$ than $78.4 \mathrm{Gg} \mathrm{day}^{-1}$ in 2010. This decreasing ratio was fitted within two estimates $(-0.7 \%$ and $-7.9 \%)$ based on the scenario analysis of the bottom-up emission inventory (Xia et al., 2016). For the Republic of Korea, the variation from 2010 to 2012 of $+4.0 \%$ officially reported by the National Institute of Environmental Research (NIER, 2018) was used, and the estimated $\mathrm{SO}_{2}$ emissions were $1.2 \mathrm{Gg}$ day $^{-1}$. For Japan, $\mathrm{SO}_{2}$ emissions may have increased owing to higher power plant use after the Fukushima Daiichi nuclear disaster (e.g., Morino et al., 2011), but emissions were kept at the 2010 level of $1.9 \mathrm{Gg} \mathrm{day}^{-1}$ due to the lack of detailed information. For other countries in the modeling domain, $\mathrm{SO}_{2}$ emissions were also not adjusted. Ship emissions did not change dramatically from 2010 to 2015 unless the clean scenario was adopted (Eyring et al., 2005); hence, we did not change the ship emissions. The anthropogenic $\mathrm{SO}_{2}$ emissions were calculated for this simulation (Fig. 2(c)). We adjusted the amount of $\mathrm{SO}_{2}$ emissions and did not change the spatial distribution pattern and emission source categories. Biogenic emissions were prepared from the Model of Emissions of Gases and Aerosols from Nature (MEGAN) (Guenther et al., 2012). Biomass burning emissions were taken from the Global Fire Emissions Database (GFED) version 4.1 (van der Werf et al., 2017). $\mathrm{SO}_{2}$ emissions from volcanoes were updated from our previous study (Itahashi et al., 2017a) based on the OMI-constrained volcanic $\mathrm{SO}_{2}$ emission database (Carn et al., 2017). In total, 21 active volcanoes were considered in the modeling domain, including 2 volcanoes in the Philippines, 1 volcano in the Northern Mariana Islands, and 3 volcanoes in eastern Russia. For the remaining 15 volcanoes located in Japan, $\mathrm{SO}_{2}$ emissions were replaced if Japan Meteorological Agency (JMA) observations were available (JMA, 2018). For the JMA observations, the $\mathrm{SO}_{2}$ emissions were measured repeatedly at each observation, and minimum, mean, and maximum values were provided. The plume height for each volcano was also provided. Monthly average mean values were used because the measurements were not taken periodically. 7 of the Japanese volcanoes were located on Kyushu on the western edge of the Japanese archipelago and close to CHAAMS (Fig. 3). The details of volcanic $\mathrm{SO}_{2}$ emissions from these 7 volcanoes are as follows. In 2012, the largest emissions were from Sakurajima, located in southern Kyushu, and were 2.81 and $1.91 \mathrm{Gg}^{-1}{ }^{-1}$ in March and April, respectively. These emissions alone surpassed the amount of anthropogenic emissions from Japan. The second and third largest emissions of around $0.7 \mathrm{Gg}$ day $^{-1}$ were from Suwanosejima and Asosan. The next largest were $0.45 \mathrm{Gg}$ day $^{-1}$ from Satsuma-Iojima. The emissions of the other 3 volcanoes, Kirishimayama, Kuchinoerabujima, and Kujusan, were relatively small. Though there were no observations at Satsuma-Iojima and Kuchinoerabujima in the study period, two observations were conducted in this year and the observed average values were used (JMA, 2018). There were no reports from JMA of the emissions from Suwanosejima and Kujusan; thus, the amount of emissions from Suwanosejima was taken from the latest summary report averaged between 2000 and 2006, and considering the current low activity of

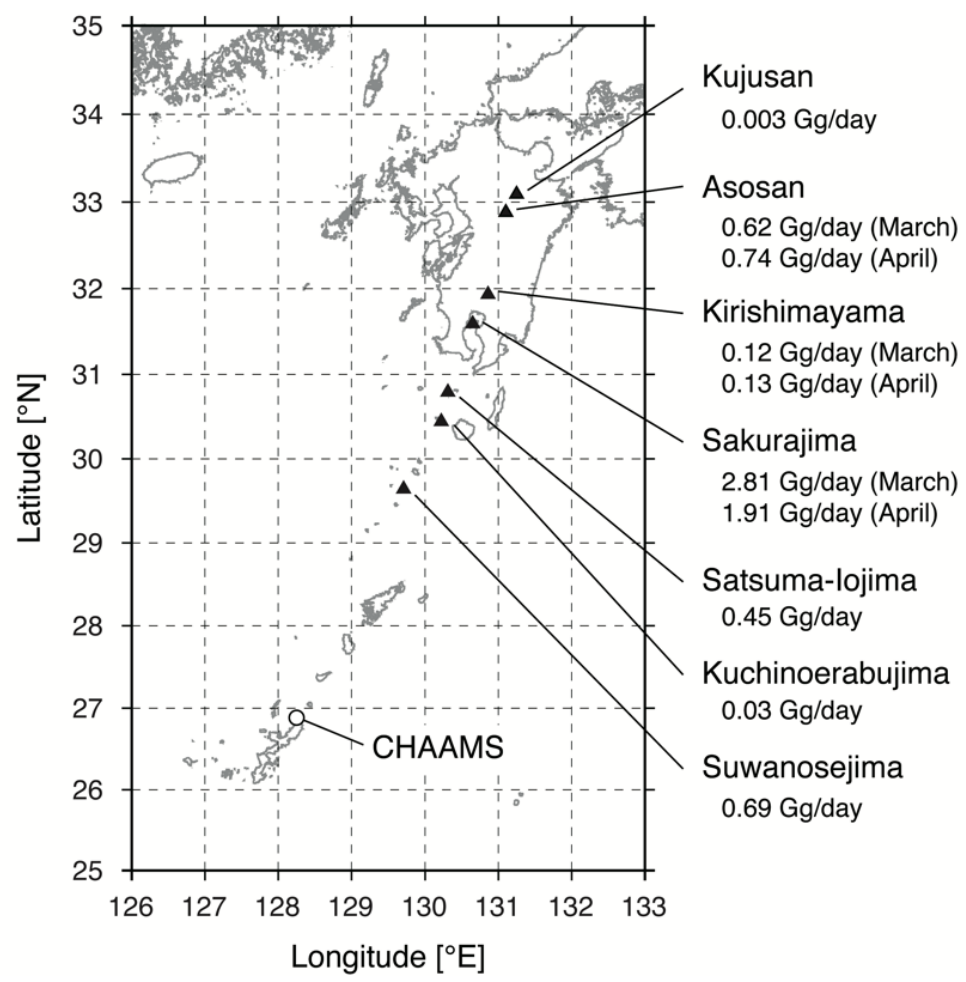

Fig. 3. Expanded map over Kyushu, Japan, showing the location of the volcanoes from which the $\mathrm{SO}_{2}$ emissions considered in this study came. 
Kujusan, the lowest value after 2004 was taken (Mori et al., 2013). Kirishimayama had a massive eruption in 2011, but the activity settled down in spring 2012 (Mori and Kato, 2013).

To estimate the sources of $\mathrm{SO}_{4}{ }^{2-}$, we used the Particulate Source Apportionment Technology (PSAT) method in CAMx (Wagstrom et al., 2008). This method assigns tracers to track the sources; hence, we refer to this method as the "tagged tracer method." This method was modified to use SAPRC-07 chemistry. The usefulness of the tagged tracer method for $\mathrm{SO}_{4}{ }^{2-}$ over East Asia with respect to the validity of the linear assumption has been reported previously (Itahashi et al., 2017a, b; Itahashi, 2018). In this study, we prepared seven source groups: five sources for anthropogenic emissions from mainland China, Taiwan, the Korean Peninsula, Japan, and other regions in the modeling domain, including the lateral boundary condition; one source for ship emissions; and one source for volcano emissions as a natural source. In this work, the source region of Japan did not include Okinawa; therefore, the source apportionment for Japan represented LRT from mainland Japan. For the detailed study in March and April characterized by different sources, we set more source groups (see "Results and Discussion”).

\section{RESULTS AND DISCUSSION}

\section{Model Evaluation and Estimation of $\mathrm{SO}_{4}{ }^{2-}$ Sources at CHAAMS}

For the meteorological field, the model results were compared with observations at CHAAMS (Fig. 4). Although the wind speed was slightly overestimated, its temporal variation was captured (Fig. 4(a)). The model overestimation was partly because CHAAMS was resolved as an ocean grid at the current model resolution, as in our previous study (Itahashi et al., 2017a). The wind direction was captured well by the model. In March, the wind direction was northerly, and then slowly changed from easterly to southerly from March 13 to 18 . In April, the wind direction changed from northerly to easterly, then southerly from April 23 to 26, and repeatedly changed from April 27 to 29 (Fig. 4(b)). The temperature was $15^{\circ} \mathrm{C}$ in March and increased to around $20^{\circ} \mathrm{C}$ in April (Fig. 4(c)). In March, there were no precipitation events greater than $1 \mathrm{~mm}$, but in April, several precipitation events occurred. On April 22, precipitation of $0.28 \mathrm{~mm}$ was observed at 05:00 LT and the model overestimated this event as $1.9 \mathrm{~mm}$. In contrast, from late April 24 to early on the 25, there was high precipitation of $10.28 \mathrm{~mm}$, but the model substantially underestimated the event as $1.3 \mathrm{~mm}$ (Fig. 4(d)). Capturing local precipitation events was difficult for the meteorological model. The relative humidity was just below $80 \%$ in March, although it reached $100 \%$ during the precipitation event on April 25, and then decreased to $60 \%$ for the rest of April (Fig. 4(e)).

The modeled $\mathrm{SO}_{2}$ and $\mathrm{SO}_{4}{ }^{2-}$ concentrations were compared with observations from CHAAMS (Fig. 5). The statistical analysis of the model results and observations based on the period mean, correlation coefficient $(R)$ with significance level determined by Student's $t$-test, mean fractional bias (MFB), and mean fractional error (MFE) are listed in Table 1. In Fig. 5, the symbol for $\mathrm{SO}_{4}{ }^{2-}$ is colored according to the observed and modeled conversion ratio (Fs) from $\mathrm{SO}_{2}$ to $\mathrm{SO}_{4}{ }^{2-}$, which is calculated from the molar concentrations by:

$$
F s=\frac{\mathrm{SO}_{4}^{2-}}{\mathrm{SO}_{2}+\mathrm{SO}_{4}^{2-}}
$$

This ratio represents the ratio of $\mathrm{SO}_{4}{ }^{2-}$ to the sum of $\mathrm{SO}_{2}$ and $\mathrm{SO}_{4}{ }^{2-}$. Because the local $\mathrm{SO}_{2}$ emissions at CHAAMS are negligible, Fs was used as the index of the LRT impact to identify whether the air mass was fresh (lower Fs) or aged (higher Fs). In our previous estimation of sources for the autumn case study at CHAAMS, Fs values below 70\% were strongly related to volcanic contributions due to their fast transport at higher altitudes, and Fs near 100\% indicated a well-aged air mass from LRT (Itahashi et al., 2017a).

For $\mathrm{SO}_{2}$ (Fig. 5(a)), based on the environmental standard criteria in Japan, days when there were less than $20 \mathrm{~h}$ of hourly observations were regarded as deficit days and are not shown (i.e., March 13, 16, and 17; April 24 and 25). On March 11 and 15, the $\mathrm{SO}_{2}$ concentration surpassed 1 ppbv, whereas in April, $\mathrm{SO}_{2}$ concentrations were low at less than 0.5 ppbv. These observed features were captured well by the model. The statistical analysis in Table 1 shows that the observed and modeled mean concentrations were similar and were significantly correlated $(R=0.90, p$ $<0.001)$. During the observation period in 2012, there were unusually high concentrations of $\mathrm{SO}_{4}{ }^{2-}$ in March and April (Fig. 5(b)), as shown in Fig. 1. On March 15, the daily mean $\mathrm{SO}_{4}{ }^{2-}$ concentration was $16.91 \mu \mathrm{g} \mathrm{m}{ }^{-3}$. However, the model did not reproduce this high concentration. In April, the highest daily mean $\mathrm{SO}_{4}{ }^{2-}$ concentration of $15.87 \mu \mathrm{g} \mathrm{m}^{-3}$ was observed on April 23 and the second highest of $8.08 \mu \mathrm{g} \mathrm{m}^{-3}$ was observed on April 22, and these high concentrations were simulated well by the model. From the statistical analysis (Table 1), MFB and MFE for $\mathrm{SO}_{4}{ }^{2-}$ were within the performance goal criteria proposed by Boylan and Russell (2006) for models. During the observation campaign in spring 2012, Fs values were well reproduced (Table 1), suggesting that the air mass aging at CHAAMS was captured by the model in addition to the concentrations of $\mathrm{SO}_{2}$ and $\mathrm{SO}_{4}{ }^{2-}$.

The sources of $\mathrm{SO}_{4}{ }^{2-}$ estimated by the tagged tracer method are shown as the daily mean in Fig. 5(c). High concentrations on March 14 and 15 were characterized by lower Fs values (Fig. 5(b)) and the wind direction was northerly to easterly (Fig. 4(b)); hence, volcanoes were identified as an important source. By contrast, during the high-concentration episode in April, featuring a well-aged air mass of higher Fs (Fig. 5(b)) and change in wind direction from north to south, the anthropogenic emissions from China were identified as the dominant source. In the following sections, we analyze these unusual high-concentration episodes that occurred in March and April further by focusing on volcanic emissions and anthropogenic emissions from China, respectively. 
(a)

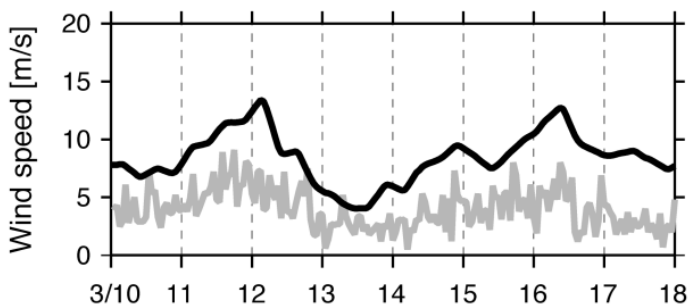

(b)

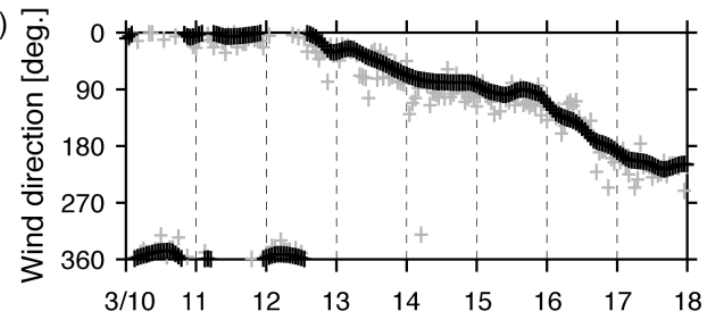

(c)

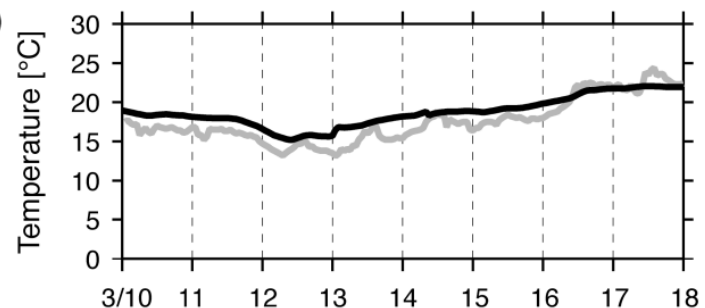

(d)

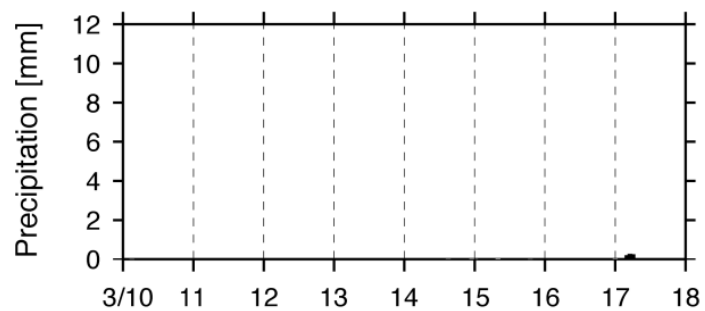

(e)

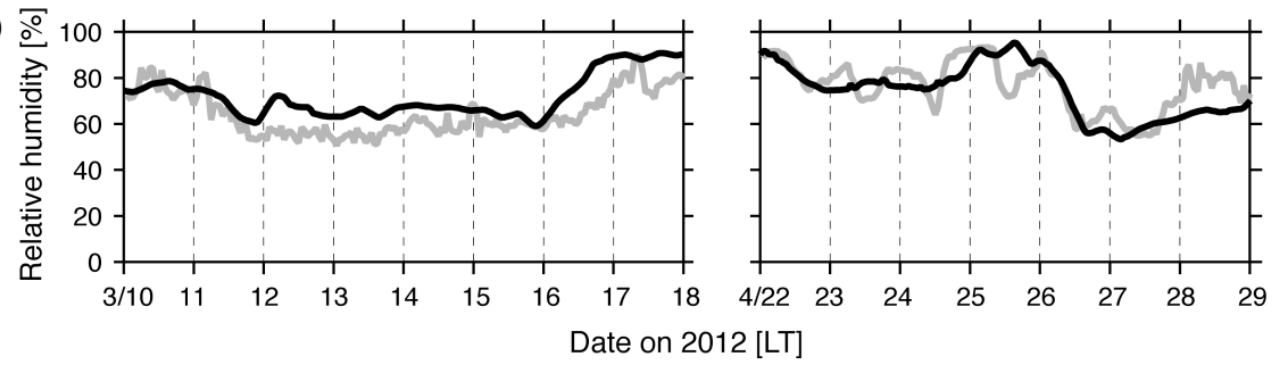

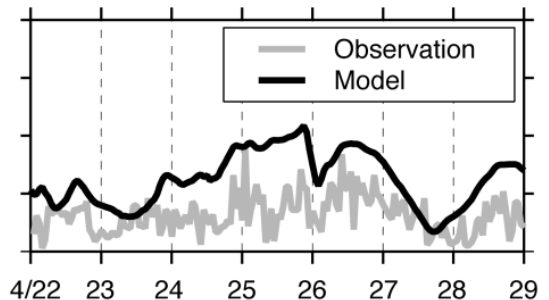
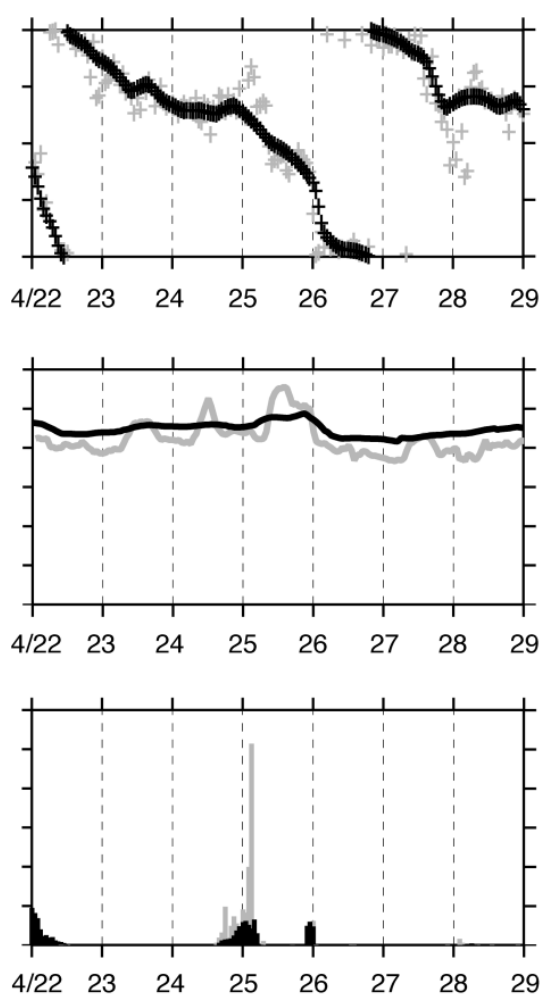

Fig. 4. Temporal variation of the meteorological fields of (a) wind speed, (b) wind direction, (c) temperature, and (d) relative humidity for observations (gray) and the model (black).

\section{$\mathrm{SO}_{4}{ }^{2-}$ Sources for the High-concentration Episode in March}

Three unusually high concentrations of 11.68, 10.83, and $16.91 \mu \mathrm{g} \mathrm{m}^{-3}$ were observed on March 11, 14, and 15, respectively; however, these concentrations were all underestimated by the model. On March 11, compared with the other two days of high concentrations, the standard deviation of the model used to derive the daily mean was large (Fig. 5(b)), and the hourly modeled $\mathrm{SO}_{4}{ }^{2-}$ concentration ranged from 1.5 to $16.2 \mu \mathrm{g} \mathrm{m}^{-3}$. In addition, the model slightly underestimated Fs. Therefore, a more stagnant air mass may explain this peak. Compared with March 11, the 
(a)
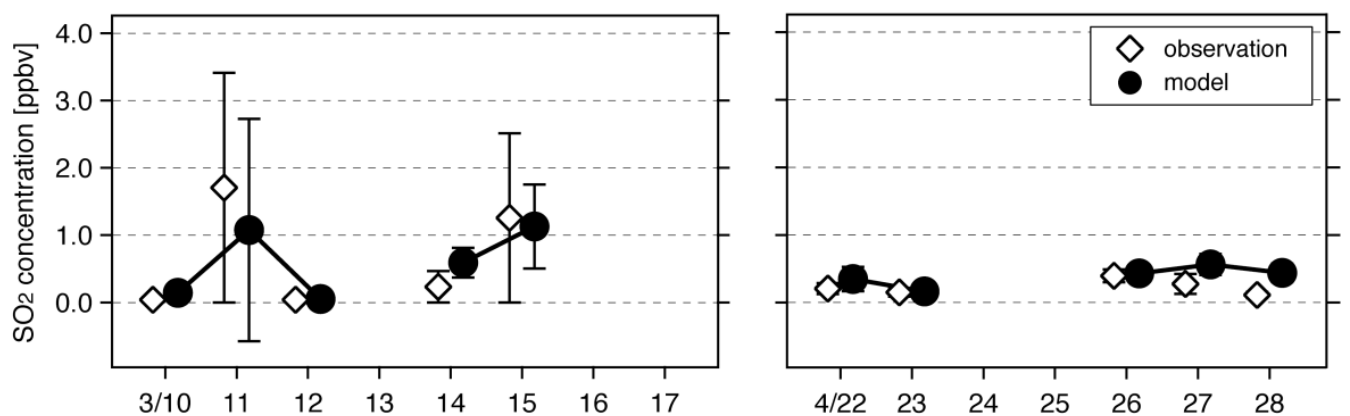

(b)
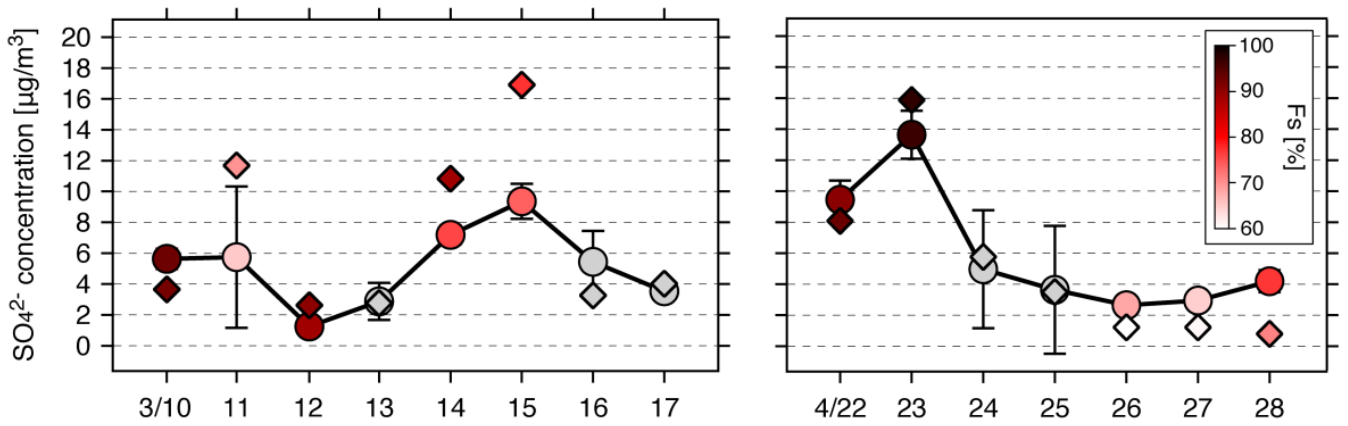

(c)

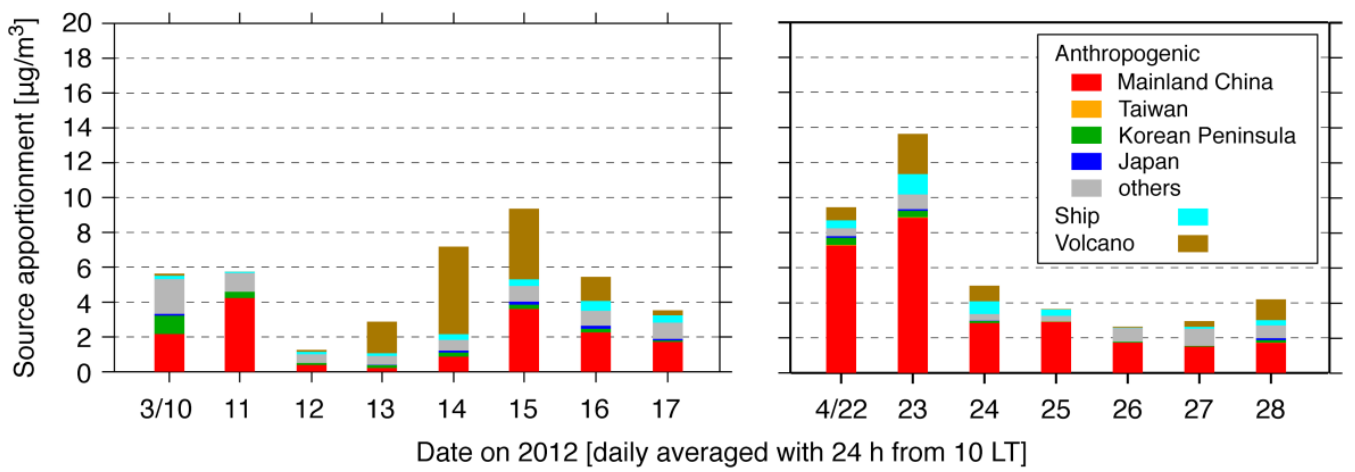

Fig. 5. Temporal variation of (a) $\mathrm{SO}_{2}$ and (b) $\mathrm{SO}_{4}{ }^{2-}$ concentrations. The whiskers indicate the standard deviation of the daily mean value. Observations and model results are shown in white and black, respectively, in (a). Observed and modeled Fs values are shown in red in (b). (c) Temporal variation in modeled source apportionments.

Table 1. Summary of the statistical analysis for $\mathrm{SO}_{2}, \mathrm{SO}_{4}{ }^{2-}$, and Fs during the observation campaign in March and April 2012.

\begin{tabular}{llll}
\hline & $\mathrm{SO}_{2}$ & $\mathrm{SO}_{4}{ }^{2-}$ & Fs \\
\hline$N$ & 10 & 15 & 10 \\
Mean (observation) $^{a}$ & 0.53 & 6.15 & 79.26 \\
Mean (model) $^{a}$ & 0.53 & 5.50 & 79.16 \\
$R$ & $0.90(p<0.001)$ & $0.84(p<0.001)$ & $0.87(p<0.001)$ \\
MFB [\%] & +21.29 & +8.64 & +0.74 \\
MFE [\%] & +50.07 & +45.93 & +7.54 \\
\hline
\end{tabular}

${ }^{a}$ Units are ppbv for $\mathrm{SO}_{2}, \mu g \mathrm{~m}^{-3}$ for $\mathrm{SO}_{4}{ }^{2-}$, and $\%$ for Fs.

the contribution of volcanoes was the largest at $70.2 \%$ and $40.8 \%$, surpassing that of anthropogenic emissions from China of $12.0 \%$ and $38.4 \%$, respectively. Kyushu has many active volcanoes, and our previous studies demonstrated that volcanoes are an important source of $\mathrm{SO}_{4}{ }^{2-}$ in Japan (Itahashi et al., 2017a, b; Itahashi, 2018). Therefore, we examined the source apportionment of individual volcanoes in Japan further. Considering the $\mathrm{SO}_{2}$ emissions (Fig. 3), the source apportionments of four main active volcanoes of Sakurajima, Suwanosejima, Asosan, and Satsuma-Iojima on Kyushu are shown (Fig. 7). Sakurajima, which emitted the largest amount of $\mathrm{SO}_{2}$ that surpassed the anthropogenic emissions from Japan (Fig. 3), was identified as the dominant volcano source in March (Fig. 7(a)). Its apportionments were estimated as 2.49 and $3.05 \mu \mathrm{g} \mathrm{m}^{-3}$ on March 14 and 15 , which were $34.7 \%$ and $32.6 \%$ of the modeled $\mathrm{SO}_{4}{ }^{2-}$ 
March 14, 2012

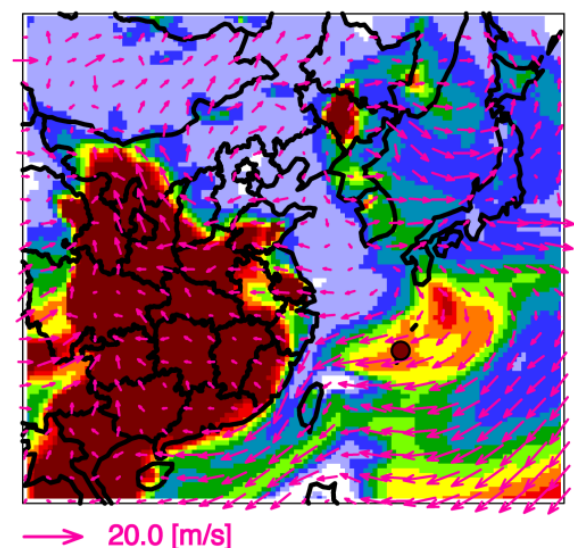

March 15, 2012

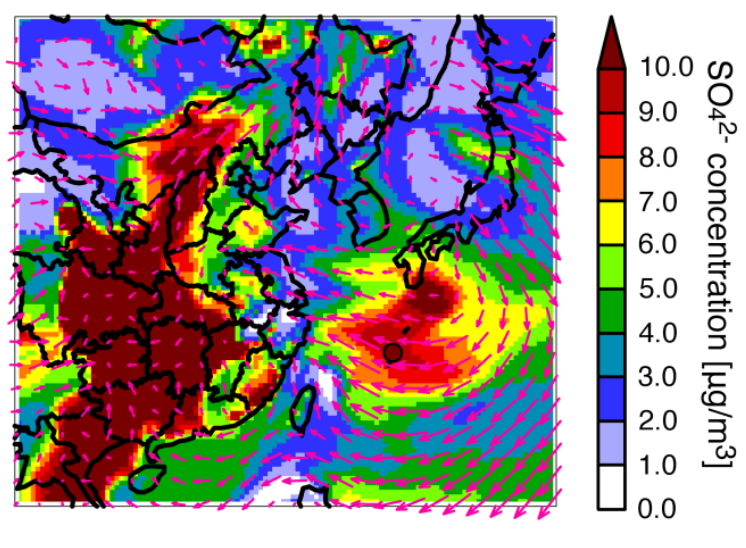

Fig. 6. Spatial distribution of modeled $\mathrm{SO}_{4}{ }^{2-}$ concentrations on March 14 and 15, 2012.

(a) Sakurajima

March 14, 2012

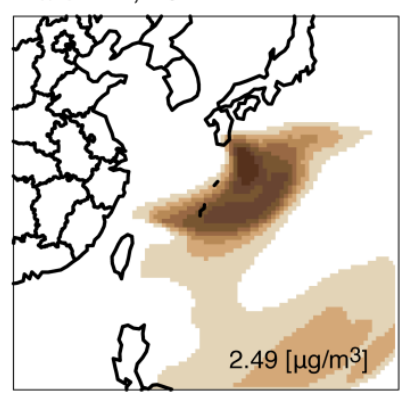

March 15, 2012

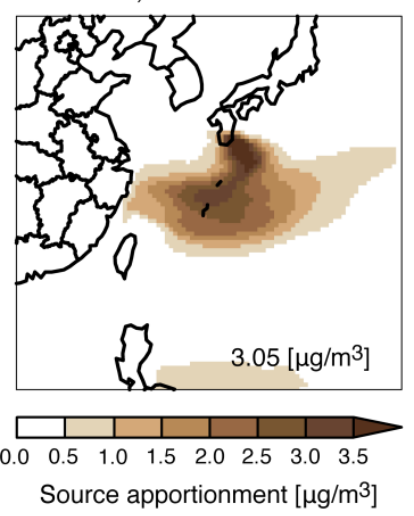

(b) Suwanosejima
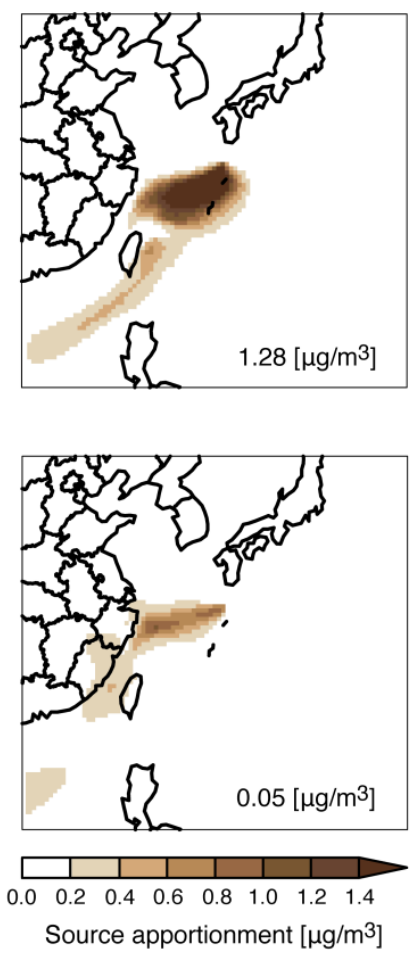

(c) Asosan
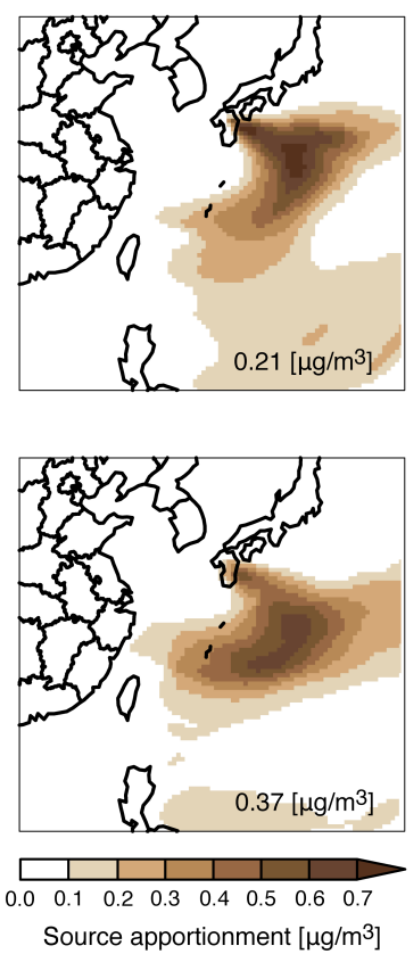

(d) Satsuma-Iojima
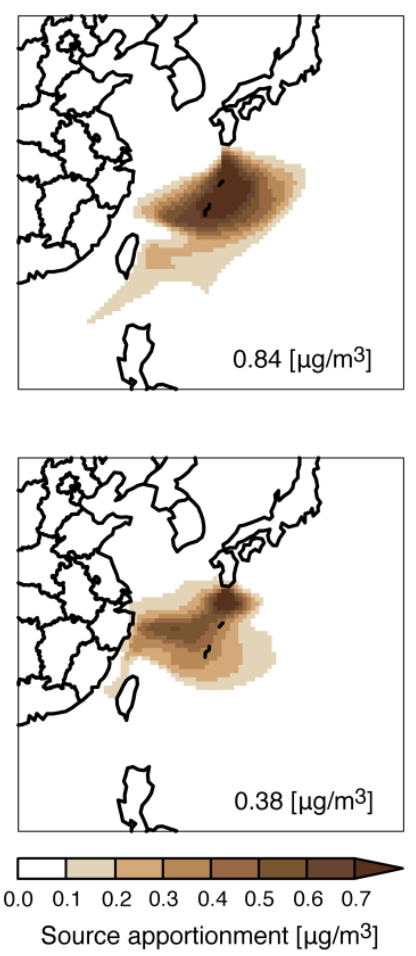

Fig. 7. Spatial distribution of modeled source apportionments for volcanic sources of (a) Sakurajima, (b) Suwanosejima, (c) Asosan, and (d) Satsuma-Iojima on (top) March 14, 2012, and (bottom) March 15, 2012. The values of the source apportionments at CHAAMS are shown in the bottom-right corner of each panel. Note the different color scale.

concentration, respectively. The second largest $\mathrm{SO}_{2}$ emitter, Suwanosejima, located nearest to CHAAMS (Fig. 7(b)) had a contribution of $1.28 \mu \mathrm{g} \mathrm{m}^{-3}$ on March 14 , whereas its contribution was negligible $\left(0.05 \mu \mathrm{g} \mathrm{m}^{-3}\right)$ on March 15 due to the strong easterly wind around CHAAMS (Figs. 4(b) and 6). The spatial distributions of the source apportionments of Asosan and Satsuma-Iojima showed similar patterns to that of Sakurajima. Due to the smaller $\mathrm{SO}_{2}$ emissions from these volcanoes, on March 14 and 15, the apportionments of Asosan were 0.21 and $0.37 \mu \mathrm{g} \mathrm{m} \mathrm{m}^{-3}$, and those of
Satsuma-Iojima were 0.84 and $0.38 \mu \mathrm{g} \mathrm{m}{ }^{-3}$, respectively. These four main volcanoes on Kyushu accounted for over $97 \%$ of the source apportionment of the total volcanic sources, and the spatial distribution of these volcanoes corresponded well to the high-concentration flow from Kyushu to CHAAMS (Fig. 6).

Further sensitivity simulations were conducted for Sakurajima, which was the main source for the highconcentration episode in March. Considering the uncertainties of $\mathrm{SO}_{2}$ emissions from volcanoes, sensitivity simulations 
were performed for the emission amount and injection height (Table 2). In these sensitivity simulations, the $\mathrm{SO}_{2}$ emission amounts from Sakurajima were increased to the estimated maximum value of $4.00 \mathrm{Gg}$ day $^{-1}$. This was 1.43 times the mean value. The JMA reported minimum, mean, and maximum $\mathrm{SO}_{2}$ measurements for each observation, indicating the uncertainty of $\mathrm{SO}_{2}$ measurements. A large eruption on March 12 was reported; therefore, we used the maximum values and this setting increased the $\mathrm{SO}_{4}{ }^{2-}$ concentration (Case A). The other parameter considered in the sensitivity simulations was the injection height of volcanic $\mathrm{SO}_{2}$ emissions, because the plume height of a volcano can vary widely. In the standard simulation, the average injection height was about $1000 \mathrm{~m}$, and this value was reduced to $750 \mathrm{~m}$ (Case B) and increased to $1500 \mathrm{~m}$ (Case $\mathrm{C}$ ) according to the estimated minimum and maximum injection heights.

The results of these sensitivity simulations as changes from the standard simulation (Fig. 7(a)) are shown in Fig. 8. The spatial distributions on March 14 and 15 and the curtain plot averaged from $126^{\circ}$ to $133^{\circ}$ longitude (region in the pink rectangle) to cover the volcanic plume within $3 \mathrm{~km}$ are shown. As expected, the maximum $\mathrm{SO}_{2}$ emissions from Sakurajima increased the $\mathrm{SO}_{4}{ }^{2-}$ concentration at CHAAMS in Case A. These increases were 0.58 and $1.02 \mu \mathrm{g} \mathrm{m}^{-3}$ on March 14 and 15, respectively. The curtain plot clarified that these increases were effectively found within the planetary boundary layer (PBL) around $1000 \mathrm{~m}$ over the ocean. Therefore, the lowest injection height in Case $\mathrm{B}$ increased the contribution from Sakurajima to the $\mathrm{SO}_{4}{ }^{2-}$ concentration at CHAAMS further, by 1.07 and $0.95 \mu \mathrm{g} \mathrm{m}^{-3}$ on March 14 and 15, respectively. In contrast, the highest injection height, approximately $1500 \mathrm{~m}$, in Case $C$ was above the PBL; hence, the effects were over a broader downwind region, and the impact on the $\mathrm{SO}_{4}{ }^{2-}$ concentration at CHAAMS was reduced. The statistical analysis confirming the model performance in March 2012 is given in Table 3. In the standard simulation, the model performed within the performance goal criteria proposed by Boylan and Russell (2006), and the performance was improved further in Cases A and B, whereas it deteriorated by a non-significant amount in Case $\mathrm{C}$. The sensitivity simulations demonstrated the importance of the injection height as well as the emission amount in accurately capturing the impact of volcanoes.

\section{$\mathrm{SO}_{4}{ }^{2-}$ Sources for the High-concentration Episode in April}

Source apportionments for China were found throughout April 2012, and the high concentration observed on April 12 was captured well by the model. A similar dominant effect from China was previously reported based on aerial observations over the East China Sea during spring (Hatakeyama et al., 1997, 2011). We have already reported seasonal and annual mean source apportionments over Japan (Itahashi et al., 2017b). To improve our knowledge of source apportionment at specific sites, we have reported the source apportionment at CHAAMS during the intensive field campaign in autumn 2015 (Itahashi et al., 2017a). To achieve detailed source apportionment for China, mainland China was separated into 31 regions (22 provinces, 4 municipalities, and 5 autonomous regions). Due to the horizontal grid resolution of $36 \mathrm{~km}$, the special administrative regions of Hong Kong and Macau were included in Guangdong Province. We focused on provincial-scale source apportionment, and then we estimated and compared the averaged and daily specific source apportionment.

The modeled spatial distributions of $\mathrm{SO}_{4}{ }^{2-}$ on April 22 and 23, when the highest concentration was obtained, are shown in Fig. 9. The isolated high-concentration plume over the East China Sea to Kyushu and CHAAMS was found on April 22, and the polluted air mass from northeastern China to the Korean Peninsula, and western Japan was observed on April 23. The source apportionments of mainland China are shown in Fig. 10. The high-concentration plume in Fig. 9 corresponded well with the source apportionment from China. The apportionments for China were 7.26 and $8.84 \mu \mathrm{g} \mathrm{m}^{-3}$ on April 22 and 23 and these were $76.8 \%$ and $64.8 \%$ of the modeled $\mathrm{SO}_{4}{ }^{2-}$ concentration, respectively. Throughout April 2012, mainland China was the largest $\mathrm{SO}_{4}{ }^{2-}$ source with a contribution of $3.82 \mu \mathrm{g} \mathrm{m}^{-3}$ accounting for $62.1 \%$ of the modeled concentration.

In the detailed source apportionment results in Fig. 11, each source apportionment for 31 source regions in China was averaged over April, and over April 22 and 23. The emission amounts estimated in this study are also shown in the order of the amount. Shandong and Jiangsu Provinces, which are the first and seventh largest anthropogenic $\mathrm{SO}_{2}$ emission sources in China, were revealed as the important sources in April. The averaged source apportionment from Shandong Province was $1.22 \mathrm{\mu g} \mathrm{m}^{-3}$, and that from Jiangsu Province was $1.12 \mu \mathrm{g} \mathrm{m}^{-3}$. These apportionments accounted for relative percentages of $32.0 \%$ and $29.4 \%$, respectively, of the total apportionments of anthropogenic emissions from China. Other important sources regions were Zhejiang, Hebei, and Anhui Provinces; these apportionments were less than $0.2 \mu \mathrm{g} \mathrm{m}^{-3}$, and accounted for relative percentages of around $5 \%$. The averages revealed that the emissions from Shandong and Jiangsu Provinces were dominant. However, we examined the day-to-day variation, especially during the high-concentration episode, in greater detail. The spatial distributions for Shandong and Jiangsu Provinces are shown in Figs. 10(b) and 10(c). On April 22, the apportionment from Shandong Province was $1.86 \mu \mathrm{g} \mathrm{m}^{-3}$,

Table 2. Explanation of sensitivity analysis for volcanic $\mathrm{SO}_{2}$ emissions from Sakurajima.

\begin{tabular}{lll}
\hline & Emission amount & Injection height \\
\hline Case A & Highest (1.43 times standard simulation) & Mean (c.a. $1000 \mathrm{~m}$; same as standard simulation) \\
Case B & Highest (1.43 times standard simulation) & Lowest (c.a. $750 \mathrm{~m}$ ) \\
Case C & Highest (1.43 times standard simulation) & Highest (c.a. $1500 \mathrm{~m})$ \\
\hline
\end{tabular}


(a) Case A

March 14, 2012
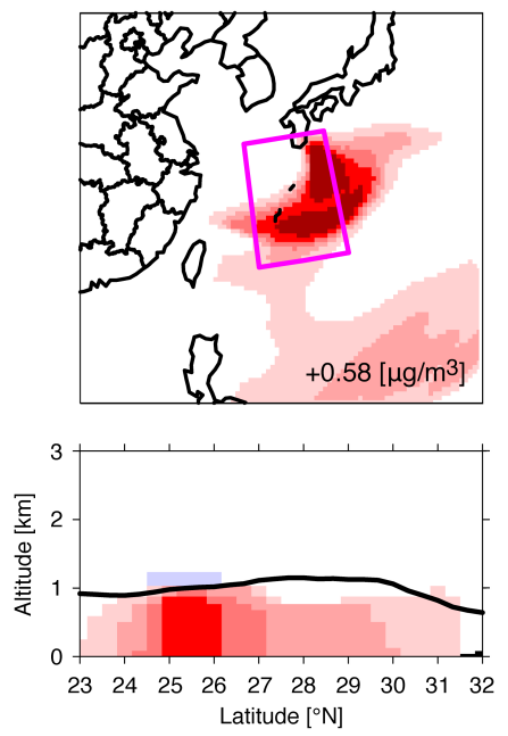

March 15, 2012
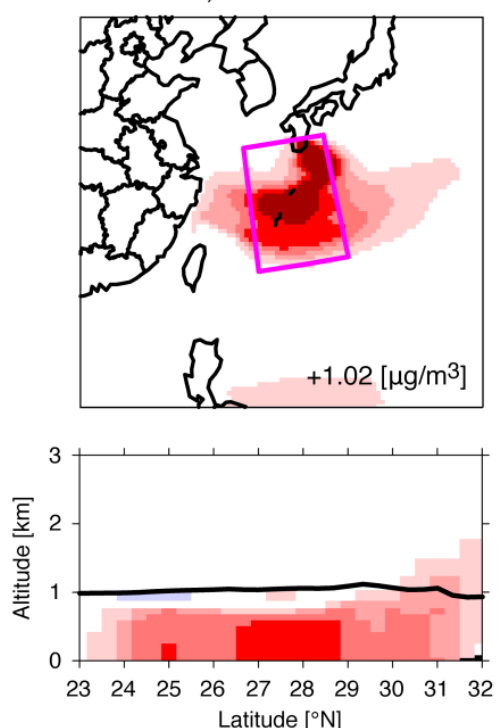

(b) Case B
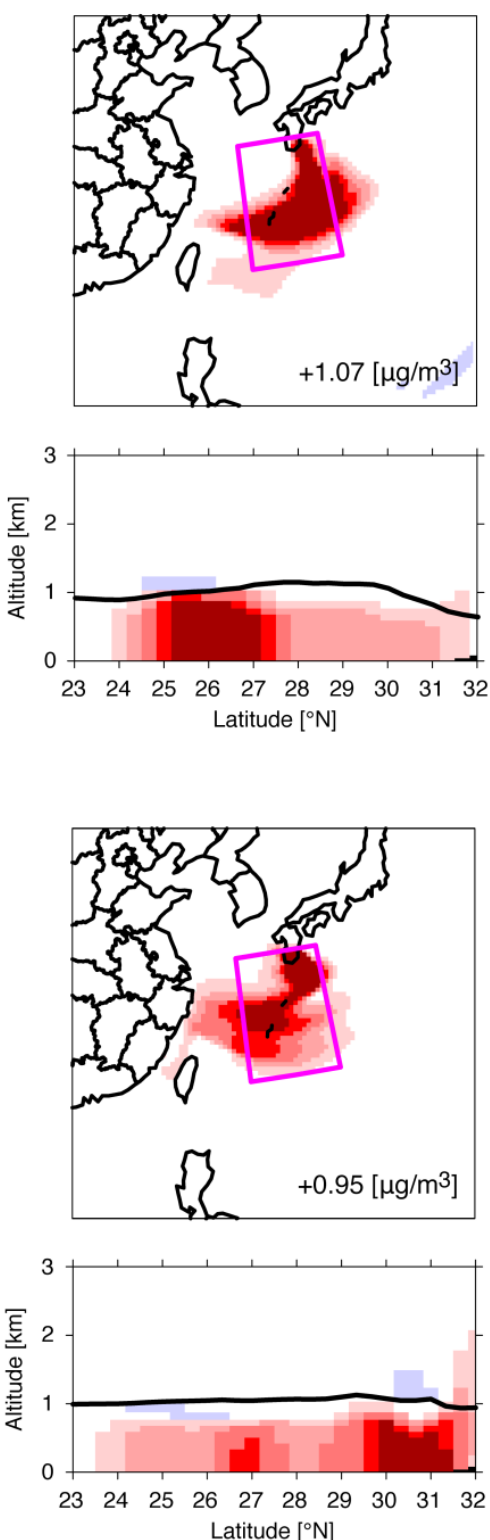

(c) Case C
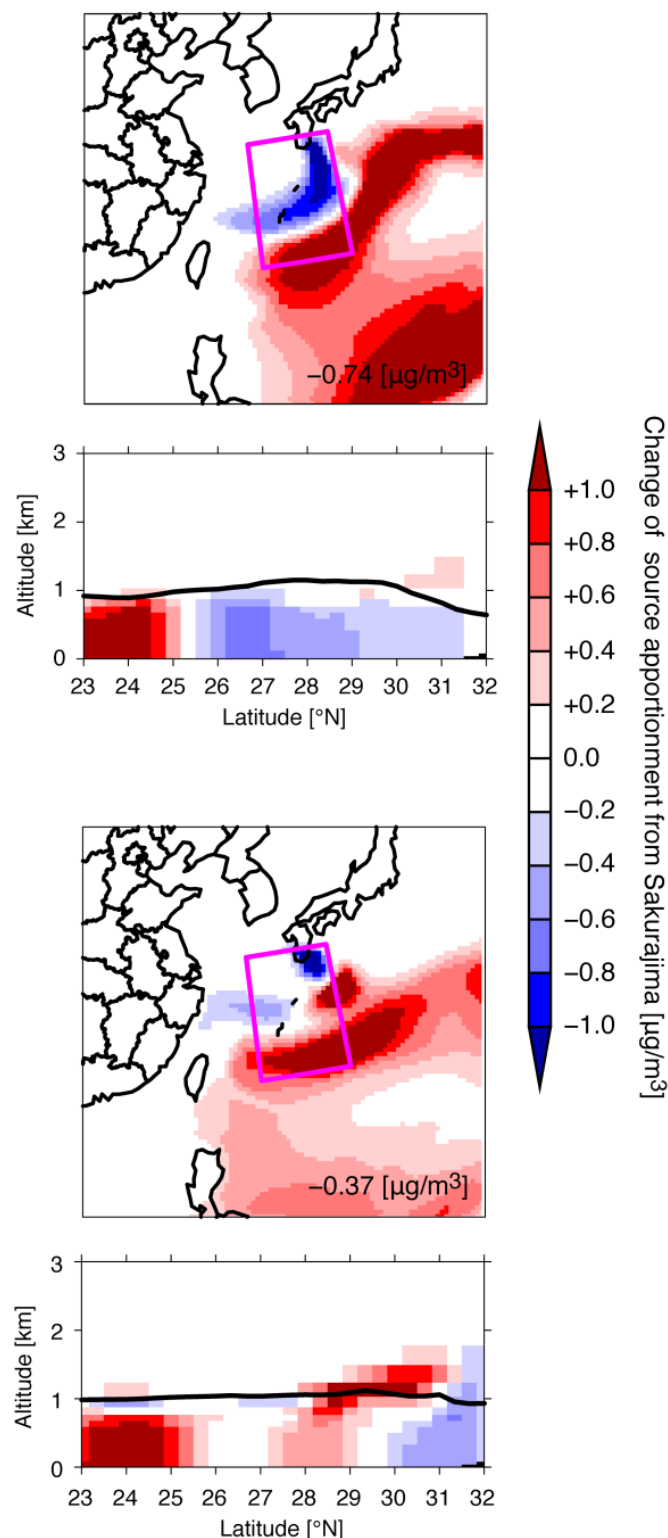

Fig. 8. Change of source apportionment from Sakurajima as a (top) spatial distribution and (bottom) curtain plot on March 14 and 15, 2012, through (a) Case A, (b) Case B, and (c) Case C sensitivity simulations. The changed source apportionment values at CHAAMS are shown in the bottom-right corner of each spatial distribution panel. For the curtain plot, the source apportionment values are averaged over $126^{\circ}$ to $133^{\circ}$ longitude (pink rectangle) and are shown from 0 to $3 \mathrm{~km}$. The thick line indicates the modeled PBL height.

Table 3. Summary of the statistical analysis for $\mathrm{SO}_{4}{ }^{2-}$ through sensitivity analyses of volcanic $\mathrm{SO}_{2}$ emissions from Sakurajima during the observation campaign in March 2012.

\begin{tabular}{lllll}
\hline & Standard simulation & Case A & Case B & Case C \\
\hline$N$ & 8 & & & \\
Mean (observation) $^{a}$ & 6.97 & & & 5.12 \\
Mean (model) $^{a}$ & 5.13 & 5.37 & 5.39 & $0.77(p>0.01)$ \\
$R$ & $0.84(p<0.01)$ & $0.85(p<0.01)$ & $0.86(p<0.01)$ & -18.63 \\
MFB [\%] & -19.18 & -16.23 & -16.11 & +45.72 \\
MFE [\%] & +43.27 & +41.85 & +40.71 & \\
\hline
\end{tabular}

${ }^{a}$ Units for the mean are $\mu \mathrm{g} \mathrm{m}^{-3}$. 
April 22, 2012

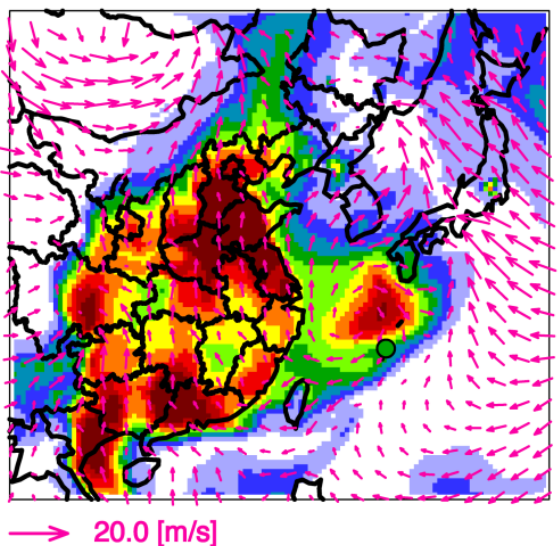

April 23, 2012

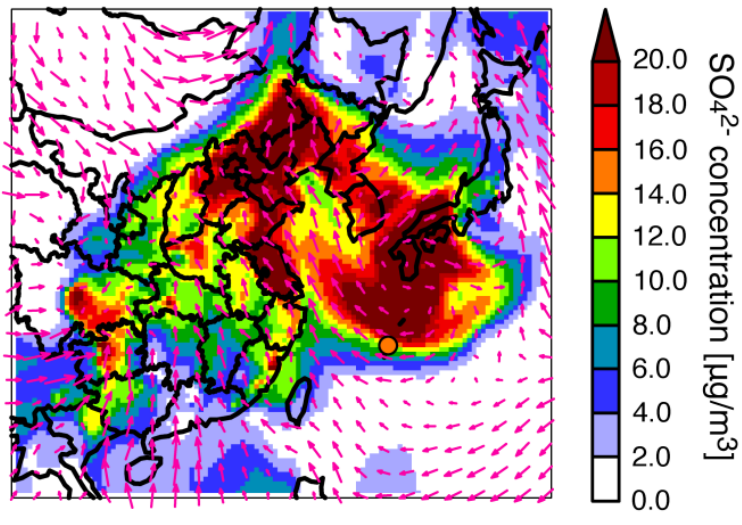

Fig. 9. Spatial distribution of modeled $\mathrm{SO}_{4}{ }^{2-}$ concentration on April 22 and 23, 2012.

(a) Mainland China

April 22, 2012

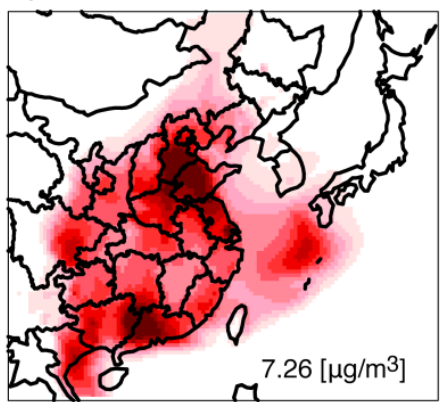

April 23, 2012

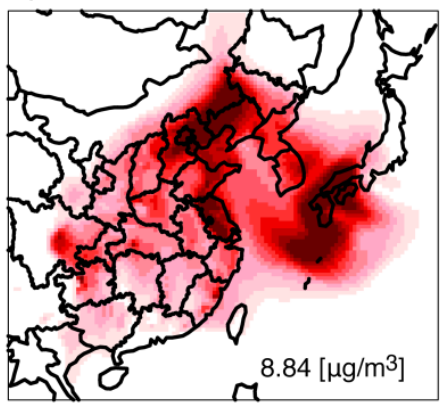

\begin{tabular}{lllllllllllll}
\hline 0 & 2 & 4 & 6 & 8 & 10 & 12 & 14 & 16 & 18 & 20
\end{tabular}

Source apportionment $\left[\mu \mathrm{g} / \mathrm{m}^{3}\right]$ (b) Shandong province
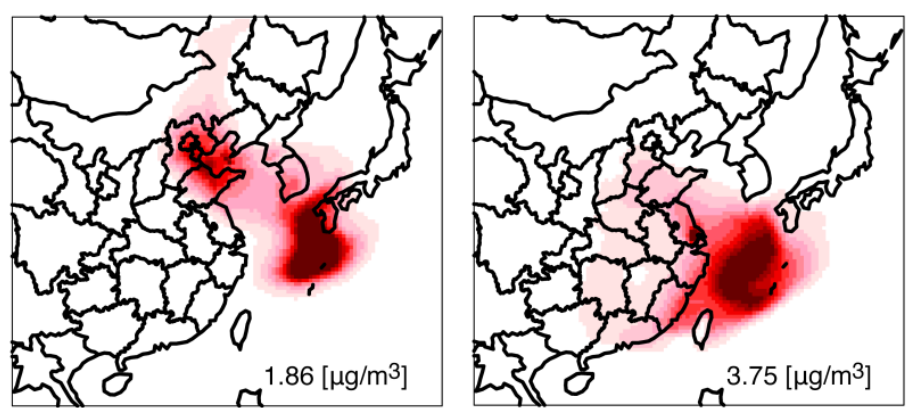

(c) Jiangsu province

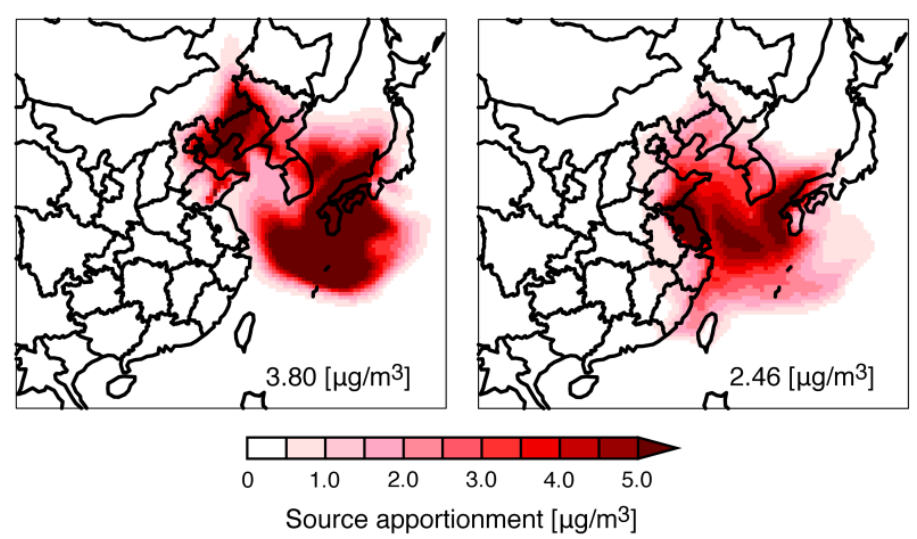

Fig. 10. Spatial distribution of modeled source apportionment for anthropogenic emissions from (a) mainland China, (b) Shandong Province, and (c) Jiangsu Province on (top) April 22, 2012, and (bottom) April 23, 2012. The source apportionment values at CHAAMS are shown in the bottom-right corner of each panel. The color scale in (a) is different from those in (b, c).

accounting for a relative percentage of $25.6 \%$ of the total apportionments of anthropogenic emissions from China, and that from Jiangsu Province was $3.75 \mu \mathrm{g} \mathrm{m}^{-3}$, accounting for $51.6 \%$. Both apportionments were found around CHAAMS as an isolated air mass. On April 23, the apportionment from Shandong Province was $3.80 \mu \mathrm{g} \mathrm{m}^{-3}$ accounting for $43.0 \%$, and that from Jiangsu Province was $2.46 \mu \mathrm{g} \mathrm{m}^{-3}$ accounting for $27.8 \%$. These apportionments were found from the continent to the East China Sea and CHAAMS. The important source regions were still Shandong and Jiangsu Provinces; however, the first and second rankings were switched during the high-concentration episode on April 22 and 23. In spring, these two regions were key contributors to the $\mathrm{SO}_{4}{ }^{2-}$ concentration at CHAAMS, and other seasons with different prevailing wind directions should be investigated further. 


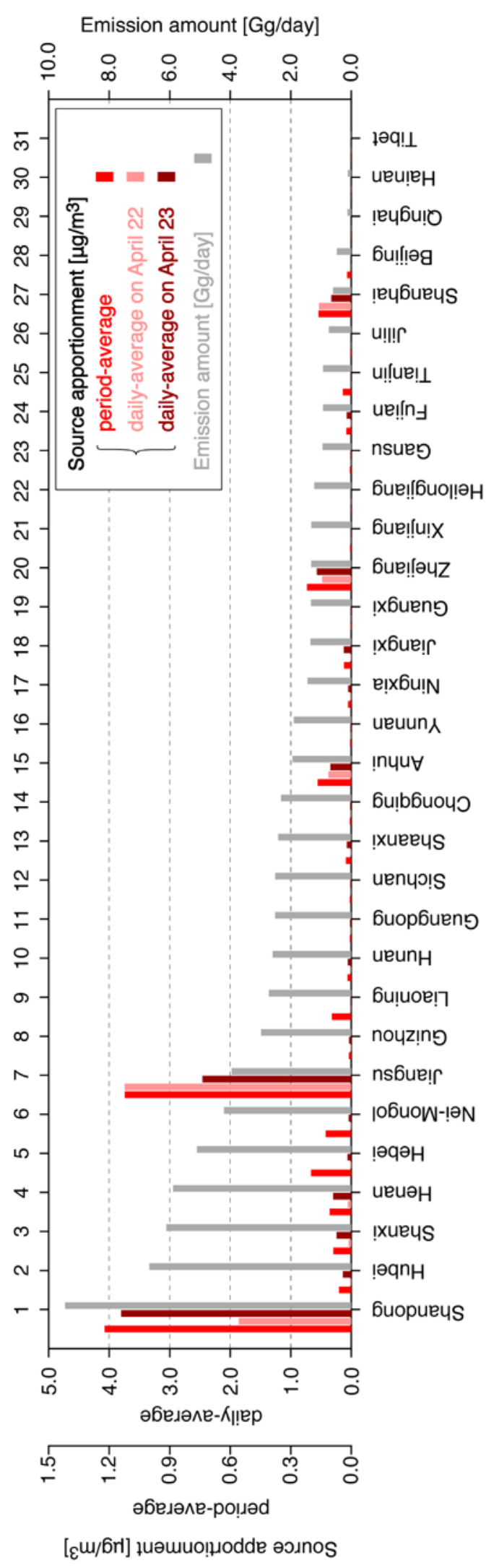

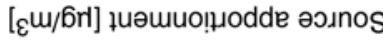

\section{CONCLUSIONS}

The continuous observation campaign from 2010 to 2015 at Cape Hedo, in the northernmost part of Okinawa, Japan (CHAAMS), reported high-concentration episodes in spring 2012. In March and April of that year, the day-today variation in $\mathrm{SO}_{4}{ }^{2-}$ at CHAAMS was evaluated using an air quality model with the tagged tracer method. The air quality model captured the observed meteorological conditions and the variation in $\mathrm{SO}_{2}, \mathrm{SO}_{4}{ }^{2-}$, and Fs. The results demonstrated that the high-concentration episodes in March 2012 were caused by volcanoes in Japan, whereas those in April were caused by anthropogenic emissions from China.

In March, Sakurajima, a volcano in southern Kyushu, was the main $\mathrm{SO}_{2}$ source, and its emissions surpassed the anthropogenic emissions from Japan in amount. Although the model performed within the performance goal criteria for March 2012, it underestimated the high-concentration peaks found on March 14 and 15. Therefore, sensitivity simulations of the emission amounts and injection heights for Sakurajima were performed. The uncertainty of $\mathrm{SO}_{2}$ emission amounts from volcanoes was one of the main reasons for the underestimation, and considering the maximum emission amount improved the model performance. In addition, the results revealed the importance of the injection height of volcanic $\mathrm{SO}_{2}$ plumes, and considering the minimum injection height, which is related to the PBL height, also improved the model performance for this episode.

In April, the $\mathrm{SO}_{4}{ }^{2-}$ was mainly attributable to anthropogenic emissions from China, and the model captured the high-concentration episode on April 22 and 23 well. The well-aged air mass suggested by higher Fs was observed. During the observation period in April, Shandong and Jiangsu Provinces were detected as the main source regions, and their first and second rankings were switched during the April 22-23 episode. These day-to-day variations identified via source apportionment will improve our understanding of the high-concentration episodes at CHAAMS.

\section{ACKNOWLEDGMENTS}

This research was supported by the Global Environment Research Fund (5-1751 and 2-1703) of the Ministry of the Environment of Japan. The authors acknowledge using MOZART-4 data for the global chemical transport model (http://www.acom.ucar.edu/wrf-chem/mozart.html) for the lateral boundary condition. The authors also thank JMA and other institutions for performing $\mathrm{SO}_{2}$ observations of Japanese volcanoes.

\section{REFERENCES}

Acid Deposition Monitoring Network in East Asia (EANET) (2013). Technical manual for air concentration monitoring in East Asia. http://www.eanet.asia/product/ manual/techacm.pdf, Last Access: 17 December 2018.

Boylan, J.W. and Russell, A.G. (2006). PM and light extinction model performance metrics, goals, and criteria 
for three-dimensional air quality models. Atmos. Environ. 40: 4946-4959.

Carmichael, G.R., Adhikary, B., D’Allura, A., Tang, Y., Streets, D., Zhang, Q., Bond, T.C., Ramanathan, V., Jamroensan, A. and Marrapu, P. (2009). Asian aerosols: Current and year 2030 distributions and implications to human health and regional climate change. Environ. Sci. Technol. 43: 5811-5817.

Carn, S.A., Fioletov, V.E., McLinden, C.A., Li, C. and Krotkov, N.A. (2009). A decade of global volcanic $\mathrm{SO}_{2}$ emissions measured from Space. Sci. Rep. 7: 44095.

Carter, W.P.L. (2010). Development of the SAPRC-07 chemical mechanism. Atmos. Environ. 44: 5324-5335.

Chatani, S., Yamaji, K., Sakurai, T., Itahashi, S., Shimadera, H., Kitayama, K. and Hayami, H. (2018). Overview of model inter-comparison in Japan's study for reference air quality modeling (J-STREAM). Atmosphere 9: 19.

Emmons, L.K., Walters, S., Hess, P.G., Lamarque, J.F., Pfister, G.G., Fillmore, D., Granier, C., Guenther, A., Kinnison, D., Laepple, T., Orlando, J., Tie, X., Tyndall, G., Wiedinmyer, C., Baughcum, S.L. and Kloster, S. (2010). Description and evaluation of the Model for Ozone and Related chemical Tracers, version 4 (MOZART-4). Geosci. Model Dev. 3: 43-67.

ENVIRON International Corporation (2016). User's guide, Comprehensive air quality model with extensions version 6.40. Ramboll Environ, Novato, USA.

Eyring, V., Kohler, H.W., Lauer, A. and Lemper, B. (2005). Emission from international shipping: 2. Impact of future technologies on scenarios until 2050. J. Geophys. Res. 110: D17306.

Guenther, A.B., Jiang, X., Heald, C.L., Sakulyanontvittaya, T., Duhl, T., Emmons, L.K. and Wang, X. (2012). The Model of Emissions of Gases and Aerosols from Nature version 2.1 (MEGAN2.1). An extended and updated framework for modeling biogenic emissions. Geosci. Model Dev. 5: 1471-1492.

Hatakeyama, S., Murano, K., Mukai, H., Sakamaki, F., Bandow, H., Watanabe, I., Yamato, M., Tanaka, S. and Akimoto, H. (1997). $\mathrm{SO}_{2}$ and sulfate aerosols over the seas between Japan and the Asian continent. Earozoru Kenkyu 12: 91-95.

Hatakeyama, S., Hanaoka, S., Ikeda, K., Watanabe, I., Arakaki, T., Sadanaga, Y., Bandow, H., Kato, S., Kajii, Y., Sato, K., Shimizu, A. and Takami, A. (2011). Aerial observation of aerosols transported from East Asia chemical composition of aerosols and layered structure of an air mass over the East China Sea. Aerosol Air Qual. Res. 11: 497-507.

Itahashi, S., Uno, I. and Kim, S.T. (2012a). Source contributions of sulfate aerosol over East Asia estimated by CMAQ-DDM. Environ. Sci. Technol. 46: 6733-6741.

Itahashi, S., Uno, I, Yumimoto, K., Irie, H., Osada, K., Ogata, K., Fukushima, H., Wang, Z. and Ohara, T. (2012b). Interannual variation in the fine-mode MODIS aerosol optical depth and its relationship to the changes in sulfur dioxide emissions in China between 2000 and 2010. Atmos. Chem. Phys. 12: 2631-2640.

Itahashi, S., Hatakeyama, S., Shimada, K., Tatsuta, S.,
Taniguchi, Y., Chan, C.K., Kim, Y.P., Lin, N.H. and Takami, A. (2017a). Model estimation of sulfate aerosol sources collected at Cape Hedo during an intensive campaign in October-November, 2015. Aerosol Air Qual. Res. 17: 3079-3090.

Itahashi, S., Hayami, H., Yumimoto, K. and Uno, I. (2017b). Chinese province-scale source apportionments for sulfate aerosol in 2005 evaluated by the tagged tracer method. Environ. Pol. 220: 1366-1375.

Itahashi, S. (2018). Toward synchronous evaluation of source apportionments for atmospheric concentration and deposition of sulfate aerosol over East Asia. J. Geophys. Res. 123: 2927-2953.

Itahashi, S., Yamaji, K., Chatani, S. and Hayami, H. (2018a). Refinement of modeled aqueous-phase sulfate production via the $\mathrm{Fe}$ - and Mn-catalyzed oxidation pathway. Atmosphere 9: 132.

Itahashi, S., Yumimoto, K., Uno, I, Hayami, H., Fujita, S., Pan, Y. and Wang, Y. (2018b). A 15-year record (20012015) of the ratio of nitrate to non-sea-salt sulfate in precipitation over East Asia. Atmos. Chem. Phys. 18: 2835-2852.

Janssens-Maenhout, G., Crippa, M., Guizzardi, F., Dentener, F., Muntean, M., Pouliot, G., Keating, T., Zhang, Q., Kurokawa, J., Wankmuller, R., Danier van der Gon, H., Kuenen, J.J.P., Kilmont, Z., Frost, G., Darras, S., Koffi, B. and Li, M. (2015). HTAP_v2.2: A mosaic of regional and global emission grid maps for 2008 and 2010 to study hemispheric transport of air pollution. Atmos. Chem. Phys. 15: 11411-11432.

Japan Meteorological Agency (JMA) (2018). http://www. data.jma.go.jp/svd/vois/data/tokyo/volcano.html, (in Japanese), Last Access: 20 March 2018.

Kaneyasu, N. (2010). Development of $\mathrm{PM}_{2.5}$ impactor for the conventional high-volume air sampler. J. Japan Soc. Atmos. Environ. 45: 171-174 (in Japanese).

Mori, T. and Kato, K. (2013). Sulfur dioxide emissions during the 2011 eruption of Shinmoedake volcano, Japan. Earth Planets Space 65: 573-580.

Mori, T., Shinohara, H., Kazahaya, K., Hirabayashi, J., Matsushima, T., Mori, T., Ohwada, M., Odai, M., Iino, H. and Miyashita, M. (2013). Time-averaged $\mathrm{SO}_{2}$ fluxes of subduction-zone volcanoes: Example of a 32-year exhaustive survey for Japanese volcanoes. J. Geophys. Res. 118: 8662-8674.

Morino, Y., Ohara, T. and Nishizawa, M. (2011). Atmospheric behavior, deposition, and budget of radioactive materials from the Fukushima Daiichi nuclear power plant in March 2011. Geophys. Res. Lett. 38: L00G11.

National Institute of Environmental Research (NIER) (2018). National Air Pollutants Emission Service, http://airemiss.nier.go.kr/mbshome/mbs/airemiss/index. do, Last Access: 20 March 2018.

Poulidis, A.P., Takemi, T., Shimizu, A., Iguchi, M. and Jenkins, S.F. (2018). Statistical analysis of dispersal and deposition patterns of volcanic emissions from Mt. Sakurajima, Japan. Atmos. Environ. 179: 305-320.

Shimada, K., Shimada, M., Takami, A., Hasegawa, S., 
Fushimi, A., Arakaki, T., Izumi, W. and Hatakeyama, S. (2015). Mode and place of origin of carbonaceous aerosols transported from East Asia to Cape Hedo, Okinawa, Japan. Aerosol Air Qual. Res. 15: 799-813.

Shimada, K., Takami, A., Kato, S., Kajii, Y., Hasegawa, S., Fushimi, A., Shimizu, A., Sugimoto, N., Chan, C.K., Kim, Y.P., Lin, N.H. and Hatakeyama, S. (2016). Characteristics of carbonaceous aerosols in large-scale Asian wintertime outflows at Cape Hedo, Okinawa, Japan. J. Aerosol Sci. 100: 97-107.

Shimada, K., Yang, X., Araki, Y., Yoshino, A., Takami, A., Chen, X., Meng, F. and Hatakeyama, S. (2017). Concentrations of metallic elements in long-rangetransported aerosols measured simultaneously at three coastal sites in China and Japan. J. Atmos Chem. 75: 123-139.

Skamarock, W.C., Klemp, J.B., Dudhia, J., Gill, D.D., Barker, D.M., Duda, M.G., Huang, X.Y., Wang, W. and Powers, J.G. (2008). A description of the advanced research WRF version 3. NCAR Technical Note NCAR/TN-475+STR. National Center for Atmospheric Research, Boulder, USA, p. 113.

Streets, D.G., Bond, T.C., Carmichael, G.R., Fernandes, S.D., Fu, Q., He, D., Klimont, Z., Nelson, S.M., Tsai, N.Y., Wang, M.Q., Woo, J.H. and Yarberl, K.F. (2003). An inventory of gaseous and primary aerosol emissions in Asia in the year 2000. J. Geophys. Res. 108: 8809.

Takami, A., Miyoshi, T., Shimono, A., Kaneyasu, N., Kato, S., Kajii, Y. and Hatakeyama, S. (2007). Transport of anthropogenic aerosols from Asia and subsequent chemical transformation. J. Geophys. Res. 112: D22S31.

Takiguchi, Y., Takami, A., Sadanaga, Y., Lun, X., Shimizu, A., Matsui, I., Sugimoto, N., Wang, W., Bandow, H. and Hatakeyama, S. (2008). Transport and transformation of total reactive nitrogen over the East China Sea. J. Geophys. Res. 113: D10306.

Taniguchi, Y., Shimada, K., Takami, A., Lin, N.H., Chan, C.K., Kim, Y.P. and Hatakeyama, S. (2017). Transboundary and local air pollutants in western Japan distinguished on the basis of ratios of metallic elements in size-segregated aerosols. Aerosol Air Qual. Res. 17: 3141-3150.

Tatsuta, S. Shimada, K., Chan, C.K., Kim, Y.P., Lin, N.H., Takami, A. and Hatakeyama, S. (2017). Contributions to long-range transported and locally emitted nitrate in size-segregated aerosols in Japan at Kyushu and Okinawa. Aerosol Air Qual. Res. 17: 3119-3127.

van der A, R.J., Mijling, B., Ding, J., Koukouli, M.E., Liu, F., Li, Q., Mao, H. and Theys, N. (2017). Cleaning up the air: Effectiveness of air quality policy for $\mathrm{SO}_{2}$ and $\mathrm{NO}_{\mathrm{x}}$ emissions in China. Atmos. Chem. Phys. 17: 17751789.

van der Werf, G.R., Randerson, J.T., Giglio, L., van Leeuwen, T.T., Chen, Y., Rogers, B.M., Mu, M., van Marle, M.J.E., Morton, D.C., Collatz, G.J., Yokelson, R.J. and Kasibhatla, P.S. (2017). Global fire emissions estimates during 1997-2016. Earth Syst. Sci. Data 9: 697-720.

Wagstrom, K.M., Pandis, S.N., Yarwood, G., Wilson, G.M. and Morris, R.E. (2008). Development and application of a computationally efficient particulate matter apportionment algorithm in a three-dimensional chemical transport model. Atmos. Environ. 42: 56505659.

Xia, Y., Zhao, Y. and Nielsen, C.P. (2016). Benefits of China's efforts in gaseous pollutant control indicated by the bottom-up emissions and satellite observations 2000-2014. Atmos. Environ. 136: 43-53.

Yumoto, Y., Shimada, K., Araki, Y., Yohino, A., Takami, A. and Hatakeyama, S. (2015). Concentration of sizesegregated aerosols transported from East Asia to cape Hedo and transformation during long-range transport. Earozoru Kenkyu 30: 115-125.

Received for review, September 18, 2018 Revised, December 26, 2018 Accepted, January 23, 2019 